\title{
Narrow rows and high maize plant population improve water use and grain yield under conservation agriculture
}

\author{
Stephanus J. Haarhoff $\odot$ | Pieter A. Swanepoel $\odot$
}

Department of Agronomy, Stellenbosch University, Private Bag X1, Matieland, 7602 Stellenbosch, South Africa

\section{Correspondence}

Pieter A. Swanepoel Department of Agronomy, Stellenbosch University, Private Bag X1, Matieland, 7602, Stellenbosch, South Africa. Email: pieterswanepoel@sun.ac.za

\begin{abstract}
The relationship between maize (Zea mays L.) population density and grain yield is influenced by soil and crop management strategies, including Conservation Agriculture (CA). However, little is known about the response of maize grain yield to varying plant population and/or row spacing under CA. A 3-yr study was conducted under CA to evaluate the effects of plant population and row spacing on maize grain yield, plant available soil water, and soil temperature. Plant populations ranging from 40,000 to 80,000 plants ha ${ }^{-1}$ were evaluated at three row spacings $(0.5,0.76$, and $1.0 \mathrm{~m})$. The response of maize grain yield to plant population was highly variable between seasons: it was not affected by plant population in the season with the highest early season rainfall but increased with increasing plant population in the driest season and in the season with well-distributed, near average rainfall. Higher plant populations resulted in lower soil water levels, presumably due to greater water extraction. Plant population affected soil water availability in the 20- to $80-\mathrm{cm}$ soil layer in Season 2, while plant population affected soil water availability at all soil layers except the 10- to 20- and 60- to 80-cm soil layers in Season 3. Rapid maize leaf-canopy closure provided by increased plant population and narrower row spacing is critical to adequately utilize the benefits associated with CA.
\end{abstract}

\section{1 | INTRODUCTION}

Recent global maize (Zea mays L.) grain yield increases were primarily driven by progress in genetic breeding and improved agronomic management practices (Ciampitti \& Vyn, 2012; Duvick, 2005). The development of maize hybrids with improved ability to withstand environmental stress factors has enabled producers to attain higher yields from higher plant populations (Duvick, 1997; Duvick, 2005). Improved weed and pest control strategies (Svobodová et al., 2018) and new or diversified crop rotation sequences (Berzsenyi, Győrffy,

\footnotetext{
Abbreviations: CA, conservation agriculture; DAE, days after emergence; FWC, field water capacity; PPAW, percent plant available water; PWP, permanent wilting point.
}

(C) 2019 The Authors. Agronomy Journal (C 2019 American Society of Agronomy
\& Lap, 2000) also contributed towards higher maize grain yields.

Changes in maize aboveground morphology traits have contributed to the success of modern hybrids established at high plant populations (Duvick, 2005). Leaves situated above ears of modern maize hybrids grow more vertically following decades of genetic breeding (Boomsma, Santini, Tollenaar, \& Vyn, 2009) leading to improved sunlight interception (Tetio-Kagho \& Gardner, 1988). At high plant populations, a well-developed leaf canopy cover is present. Root architecture and distribution at high plant populations is also of critical importance (Hammer et al., 2009). During water stress periods, modern and commercially available hybrids are more effective in extracting soil water at deeper soil layers, whereas older hybrids from the 20th century utilize more water from shallow soil layers (Campos, Cooper, 
Habben, Edmeades, \& Schussler, 2004). Narrowing row spacing further contributed toward the success of increased plant populations (Sangoi, 2001). Improved soil resource utilization is a benefit associated with decreased row spacing at equivalent plant populations, thereby resulting in more uniform plant-to-plant spacing, quicker leaf canopy closure, and a more uniform root distribution.

Interactions between plant population and soil tillage can also influence maize grain yield. Pittelkow et al. (2015) found lower maize grain yields under no-tillage compared to conventional tillage in a comprehensive global meta-analysis. Poor crop establishment, waterlogging in poorly drained soils, and subsoil compaction have been listed as factors leading to the reduced yield under no-tillage (Derpsch et al., 2014; Halvorson, Mosier, Reule, \& Bausch, 2006; Iragavarapu \& Randall, 1995). In addition, plant population and row spacing have a strong influence on maize grain yield (Van Roekel \& Coulter, 2011). Optimum plant population and row spacing may vary with management system, such as no-tillage, to maximize maize grain yield and improve soil resource-use efficiency (Haarhoff \& Swanepoel, 2018). Numerous studies have been conducted over the past few decades to investigate the response of maize grain yield to plant population and row spacing under rainfed conditions in a wide range of rainfall regions (Alessi \& Power, 1974; Balkcom, Satterwhite, Arriaga, Price, \& Van Santen, 2011; Pretorius \& Human, 1987; Qian et al., 2016; Westgate, Forcella, Reicosky, \& Somsen, 1997; Widdicombe \& Thelen, 2002). Optimum plant populations and row spacings differ between conventional tillage and no-tillage systems (Haarhoff \& Swanepoel, 2018). Between 1966 and 2017, only 40 out of 104 trials investigating the response of maize grain yield at varying plant population and/or row spacing were performed under no-tillage, with less than $10 \%$ performed under conservation agriculture (CA; Haarhoff \& Swanepoel, 2018).

Conservation Agriculture is based on three principles, namely (a) crop rotation, (b) permanent organic soil cover, and (c) minimal or no soil disturbance (FAO, 2019). The benefits associated with CA include improved soil water holding capacity (Verhulst et al., 2010), increased infiltration rates (Thierfelder \& Wall, 2009), and reduced weed pressure (MacLaren, Storkey, Strauss, Swanepoel, \& DehnenSchmutz, 2018). Conservation Agriculture has been adopted largely to counter soil erosion and other forms of soil degradation, and to improve resource use efficiency. Soils under CA are associated with increased soil water content (Thierfelder \& Wall, 2009), and plant population and row spacing should be adapted accordingly.

Derpsch et al. (2014) called for a more optimized systems approach when investigating crop performances under no-tillage. Studies conducted under no-tillage often label the cropping system as "Conservation Agriculture," despite only one or two CA principles being practiced due to the practi-

\section{Core Ideas}

- Maize grain yield response to increased plant population differed between seasons.

- Soil temperature is only influenced by plant population and row spacing early in the growing season.

- Low plant population at wide row spacing results in poor soil water utilization and yield.

cal challenges of incorporating all three principles. Partially applying CA may lead to the misinterpretation of crop performances under no-tillage, crop rotation, and high residue levels and may cause concerns among farmers and crop researchers regarding the viability of CA. Despite the growing amount of research reporting on maize grain yield response to varying plant population and row spacing under no-tillage, there exists a need to investigate similar maize responses under a complete CA system. The objective of this study was to evaluate maize grain yield, soil temperature, and soil water content in response to varying plant population and row spacing configurations under $\mathrm{CA}$.

\section{2 | MATERIALS AND METHODS}

\section{1 | Site description}

Field trials were conducted near Reitz $\left(27^{\circ} 46^{\prime} \mathrm{S}, 28^{\circ} 25^{\prime} \mathrm{E}\right.$; elevation 1,630 m) in the Eastern Free State, South Africa, during the 2015-2016 (Season 1), 2016-2017 (Season 2), and 2017-2018 (Season 3) production seasons. The region is characterized by a subtropical highland climate (Cwb; Kottek, Grieser, Beck, Rudolf, \& Rubel, 2006) with a mean annual rainfall of $709 \mathrm{~mm}$. Approximately $85 \%$ of the rainfall occurs during the maize growing season (Oct.-Apr.). Soil type was a sandy-loam Typic Plinthaqualf (Soil Survey Staff, 2003) with $1.24 \%$ soil organic matter, $1.52 \mathrm{~cm}^{-3}$ soil bulk density and a $\mathrm{pH}(\mathrm{KCl})$ of 5.32 at the beginning of Season 1. According to the South African soil classification system, the soil form is a soft-eluvic Longlands (Soil Classification Working Group, 1991). Rainfall was measured at the trial site using a rain gauge. Average daily maximum temperature was recorded at a weather station approximately $40 \mathrm{~km}$ from the trial site.

\subsection{Trial design and treatments}

Three target populations $(40,000,60,000$, and 80,000 plants $\left.\mathrm{ha}^{-1}\right)$ and three row spacings $(0.50,0.76$, and $1.0 \mathrm{~m})$ were studied in a factorial arrangement using a randomized block 
design with three replications. Plots were 24-m long and consisted of 12 crop rows. A JM3080 PD planter (Jumil Pty, Castelo, Espírito Santo, Brazil) was used to establish the maize at all row spacings. The optimal seeding date in the eastern Free State range from mid-October to mid-November. However, planting is only feasible when soil moisture is adequate, thus planting was delayed beyond the optimal dates in Seasons 1 and 3. Crops were planted on 14 December 2015, 23 November 2016, and 4 December 2017. The maize cultivar DKC 7374BR (123 d to maturity) was used in all three seasons as it is one of the top yielding rainfed cultivars in the region and frequently planted by local maize producers.

The trials were established in a soybean [Glycine max (L.) Merr.]-winter sown spring wheat (Triticum aestivum L.)maize rotation system, which has been managed under notillage since 2011. The winter wheat served as a cover crop between summer grains. In Season 1, $75 \mathrm{~kg} \mathrm{ha}^{-1} \mathrm{~N}, 19 \mathrm{~kg}$ $\mathrm{ha}^{-1} \mathrm{P}$, and $9 \mathrm{~kg} \mathrm{ha}^{-1} \mathrm{~K}$ were applied at planting as the compound fertilizer 8:2:1 (28\% purity). In Seasons 2 and 3, crop nutrition was applied in two equal split applications as the compound fertilizer 6:2:1 (31\% purity): $35 \mathrm{~kg} \mathrm{ha}^{-1} \mathrm{~N}, 12 \mathrm{~kg}$ $\mathrm{ha}^{-1} \mathrm{P}$, and $6 \mathrm{~kg} \mathrm{ha}^{-1} \mathrm{~K}$ at planting and as a top-dressing at the fifth-leaf collar (V5) growth stage. Weeds were chemically controlled with pre- and post-emergence herbicides according to seasonal needs during all three seasons. Hand-weeding was done where necessary to keep all plots weed free. Crop residue cover was approximately $95 \%$ during the first few weeks after harvest. Strong winter winds lowered soil cover prior to planting and soil cover generally ranged from 40 to $55 \%$ at the end of each season.

\section{3 | Sampling and calculations}

Target plant populations were not always achieved as a result of challenging growing conditions during emergence and seedling growth and/or planter performance during all three seasons. To overcome biased reporting of results, final populations were estimated from plant counts in the central eight rows of each plot at harvest. The central eight crop rows of each plot were hand-harvested at physiological maturity to determine maize grain yield. All grain yield data were standardized to a moisture content of $12.5 \%$.

Soil temperature and water content was evaluated in Seasons 2 and 3 using AquaCheck capacitance-based soil water probes (AquaCheck, Durbanville, South Africa). The soil water probes were installed halfway between two central rows $30 \mathrm{~d}$ after emergence (DAE). Soil water content and temperature were recorded in $10-\mathrm{cm}$ increments to $80-\mathrm{cm}$ soil depth every 30 min from 30 to 120 DAE. In Season 2, the soil temperature, soil water content, and corresponding yield data were determined as the average of three plots with two similar final plant populations (28,000 and 50,200 plants $\mathrm{ha}^{-1}$ ) within the 0.5 - and $1.0-\mathrm{m}$ row spacings to ensure a sufficient number of replicates. The final plant population of the three plots grouped for each treatment did not differ by more than $10 \%$. Due to a limited number of available soil water probes in Season 3, soil temperature and water data are reported as an average across row spacings to ensure three replicates in each final plant population treatment $(35,000$ and 50,000 plants $\mathrm{ha}^{-1}$ ). Soil temperature is expressed as daily mean temperature, averaged over $30 \mathrm{~d}$ for the 30-60, 60-90, and 90-120 DAE growth stages at soil layers 0- to 10-, 10- to 20-, 20- to 40-, 40- to 60-, and 60- to 80-cm deep.

Soil water data were field calibrated as discussed by Hajdu, Yule, Bretherton, Singh, and Hedley (2019). In short, gravimetric soil samples were taken from each soil layer $(0-10,10$ $20,20-40,40-60$, and $60-80 \mathrm{~cm})$ using a hand-auger $(7-\mathrm{cm}$ diameter), while calibration readings were recorded simultaneously at the corresponding soil layers. Soil sampling was done approximately $60 \mathrm{~cm}$ from the probe locations. Probe readings were also taken in water-filled containers (saturated readings) and in the air (dry readings). Gravimetric soil water content was consequently determined following the standard gravimetric technique (Schmugge, Jackson, \& McKim, 1980). The soil samples were immediately placed in sealed containers and weighed to determine wet mass. The soil samples were oven-dried at $105^{\circ} \mathrm{C}$ until constant weight to remove all water. The gravimetric water content of each soil sample was then converted to volumetric water content by multiplying by the soil bulk density. A linear regression of calibration readings against volumetric water values was calculated and used to calculate volumetric water content from the growing season soil water readings. Soil water content of each soil layer was determined by multiplying the volumetric water content by the depth $(\mathrm{mm})$ of the particular soil layer. Soil water content was reported as percentage plant available water (PPAW), which was determined using Equation 1:

$$
\mathrm{PPAW}=\frac{\mathrm{SWC}-\mathrm{PWP}}{\mathrm{PAW}} 100
$$

where SWC is soil water content, that is, the accumulated soil water in the particular soil layer at each measurement in mm; PWP is permanent wilting point in $\mathrm{mm}$, and PAW is plant available water in $\mathrm{mm}$. Plant available water was calculated as the difference between field water capacity (FWC) and PWP (Table 1). The FWC and PWP were estimated for each soil layer using a soil water characteristics model (Saxton \& Rawls, 2006).

\section{4 | Statistical analyses}

Multiple linear regression analyses were used to investigate the effect of plant population on maize grain yield within 
TA B L E 1 Soil particle size distribution, accumulated soil water content at field water capacity (FWC), permanent wilting point (PWP), and accumulated plant available water (PAW) for each soil layer at the trial site near Reitz, South Africa

\begin{tabular}{|c|c|c|c|c|c|c|}
\hline \multirow[b]{2}{*}{ Soil layer } & \multicolumn{3}{|c|}{ Soil particle size distribution } & \multirow[b]{2}{*}{ FWC $^{\mathrm{a}}$} & \multirow[b]{2}{*}{$\mathbf{P W P}^{\mathrm{a}}$} & \multirow[b]{2}{*}{ PAW } \\
\hline & Sand & Silt & $\overline{\text { Clay }}$ & & & \\
\hline $\mathrm{cm}$ & $\%$ & $\%$ & $\%$ & $\mathrm{~mm}$ & $\mathrm{~mm}$ & $\mathrm{~mm}$ \\
\hline $10-20$ & 81 & 6 & 13 & 19.6 & 9.2 & 10.4 \\
\hline $20-40$ & 79 & 6 & 15 & 21.1 & 10.5 & 21.2 \\
\hline Total $(0-80)$ & & & & & 86.0 & \\
\hline
\end{tabular}

${ }^{a}$ Values estimated with the Soil Water Characteristics Model (Saxton \& Rawls, 2006).

each row spacing during Seasons 1-3. Grain yield per plant was also analyzed using multiple linear regression analysis across years and row spacings. Maize grain yield data were optimized by constructing a 3D quadratic spline curve to express predicted maize grain yield response to plant population and row spacing simultaneously according to procedures described by De Boor (1978). The 3D spline curve was approximated by using a sequence of third-order (cubic) polynomials. When using a bivariate data set (correlations that involve two variables, in this study plant population and row spacing), the spline procedure solves cubic equations for each data point at a regular interval to determine the curve. A surface was fitted to the XYZ coordinate data using the bicubic spline-smoothing procedure (De Boor, 1962).

Analysis of variance (ANOVA) was used to test the effects of plant population and row spacing on soil temperature and water content during Seasons 2 and 3. The restricted maximum likelihood (REML) procedure was followed with $P$-values for the significance of each variable calculated using a type III ANOVA based on Satterthwaite's approximation for degrees of freedom. Fixed effects were plant population, row spacing, and soil depth (where applicable). Block was set as a random effect in the model. Pairwise comparisons of least square means were conducted between plant population and row spacing effects that were found to be significant at $P<.05$ in the ANOVA. Statistical analyses were conducted using Statistica (version 13.5.0.17; TIBCO Software 2018).

\section{3 | RESULTS}

\section{1 | Growing conditions}

Considerable variability occurred in seasonal rainfall and rainfall distribution between the three seasons, reflecting the erratic rainfall pattern of the region (Table 2). Belowaverage rainfall (approximately 50\% of the 30-yr average seasonal rainfall) and above-average daily maximum temper- atures were recorded from October to April in Season 1, while approximately $95 \%$ of the 30 -yr average rainfall was received in Seasons 2 and 3. Overall, dry conditions characterized Season 1 and consequently resulted in low crop establishment and poor maize growth. The onset of Season 2 was considerably wetter allowing a more optimal planting date, which enabled crops to take advantage of available soil water from early vegetative growth to the silking (R1) stage. Rainfall during the kernel filling growth stage was well below the $30-\mathrm{yr}$ average; however, adequate mid-season rainfall in Season 2 provided adequate available soil water for pollination and kernel development. Despite the delayed planting in Season 3 due to the late arrival of rains, rainfall in late December improved soil water levels allowing suitable growing conditions during the early vegetative growth stages. Subsequent rainfall $(255 \mathrm{~mm})$ created drought-free conditions from the $\mathrm{R} 1$ growth stage to physiological maturity (R6).

\section{2 | Yield response to plant population and row spacing}

The response of maize grain yield to plant population and row spacing are presented in Figures 1-3. Maize grain yield increased as plant population increased during Season 1 at 0.5-, 0.76-, and 1.0-m row spacings (Figure 1a-1c). In contrast, maize grain yield was not affected significantly $(P>.05)$ by plant population in Season 2 at $0.5-, 0.76-$, and $1.0-\mathrm{m}$ row spacings (Figure 2a-2c). In Season 3, plant population had a significant effect on maize grain yield at 0.5 -, 0.76-, and 1.0-m row spacings (Figure 3a-3c). In Seasons 1 and 3, maize grain yield increased with increasing plant population at all three row spacings. In Season 2, similar trends were evident but were not statistically significant.

The response of grain yield per plant to plant population is presented in Figure 4. As plant population increased grain yield per plant decreased $(P<.001)$. A maximum grain yield per plant of approximately $158 \mathrm{~g}$ was found at a plant population of 20,000 plants $\mathrm{ha}^{-1}$. 
T A B L E 2 Monthly and total seasonal rainfall and average daily maximum temperatures recorded during the 2015-2016 (Season 1), 2016-2017 (Season 2) and 2017-2018 (Season 3) production seasons at the trial site near Reitz, South Africa

\begin{tabular}{|c|c|c|c|c|c|c|c|c|}
\hline \multirow[b]{2}{*}{ Season } & Oct. & Nov. & Dec. & Jan. & Feb. & Mar. & Apr. & Total \\
\hline & \multicolumn{8}{|c|}{ Rainfall mm } \\
\hline Season 1 & 20 & 22 & 34 & 102 & 53 & 45 & 36 & 312 \\
\hline Season 3 & 38 & 48 & 165 & 89 & 110 & 145 & 20 & 615 \\
\hline \multirow[t]{2}{*}{30 -yr average } & 79 & 96 & 110 & 114 & 91 & 84 & 48 & 622 \\
\hline & ${ }^{\circ} \mathrm{C}$ & & & & & & & \\
\hline Season 1 & 25.2 & 25.0 & 26.5 & 26.7 & 26.4 & 24.8 & 22.9 & 25.4 \\
\hline Season 2 & 24.2 & 25.1 & 25.8 & 24.9 & 24.1 & 24.4 & 22.6 & 24.4 \\
\hline Season 3 & 24.9 & 24.8 & 25.4 & 25.8 & 25.4 & 22.8 & 21.9 & 24.4 \\
\hline $30-y r$ average & 24.6 & 25.1 & 26.4 & 26.4 & 24.9 & 24.7 & 21.9 & 24.8 \\
\hline
\end{tabular}
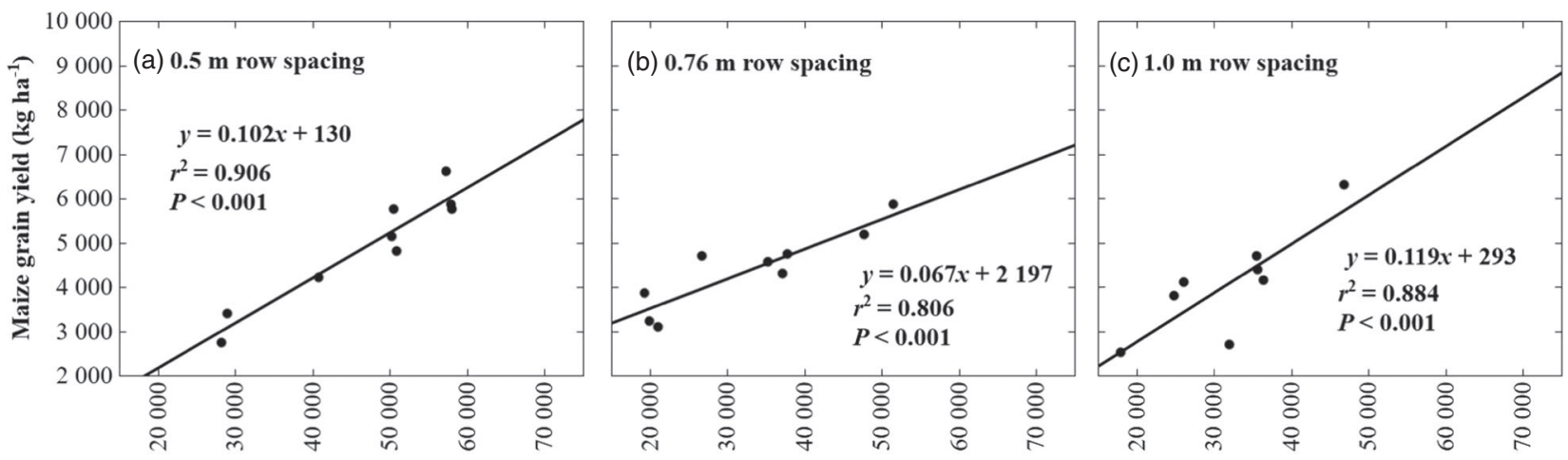

Final plant population $\left(\mathrm{ha}^{-1}\right)$

F I G URE 1 The response of maize grain yield to plant population in Season 1 at (a) 0.5-, (b) 0.76-, and (c) 1.0-m row spacing
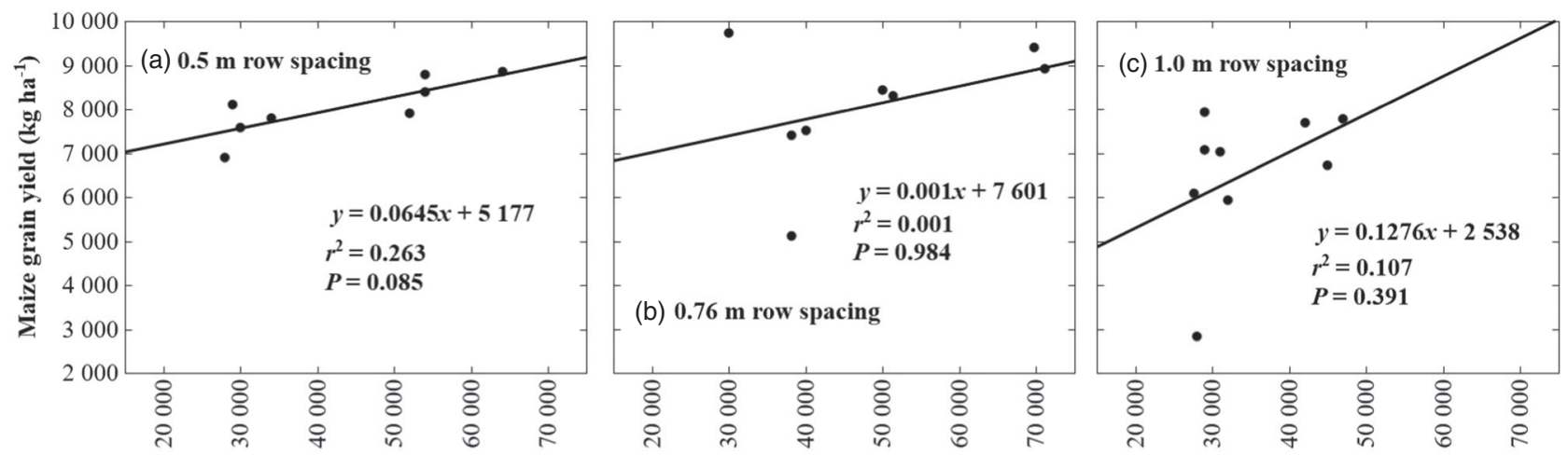

Final plant population $\left(\mathrm{ha}^{-1}\right)$

F I G U RE 2 The response of maize grain yield to plant population in Season 2 at (a) 0.5-, (b) 0.76-, and (c) 1.0 -m row spacing

\section{3 | Relationship between plant population and row spacing}

A 3D quadratic spline curve was used to express predicted maize grain yield response to various plant population and row spacing combinations (Figure 5). The contour lines were primarily arranged parallel to row spacing, indicating that row spacing had a smaller effect on maize grain yield than plant population. This observation concurs with the results reported by Haarhoff and Swanepoel (2018). The 

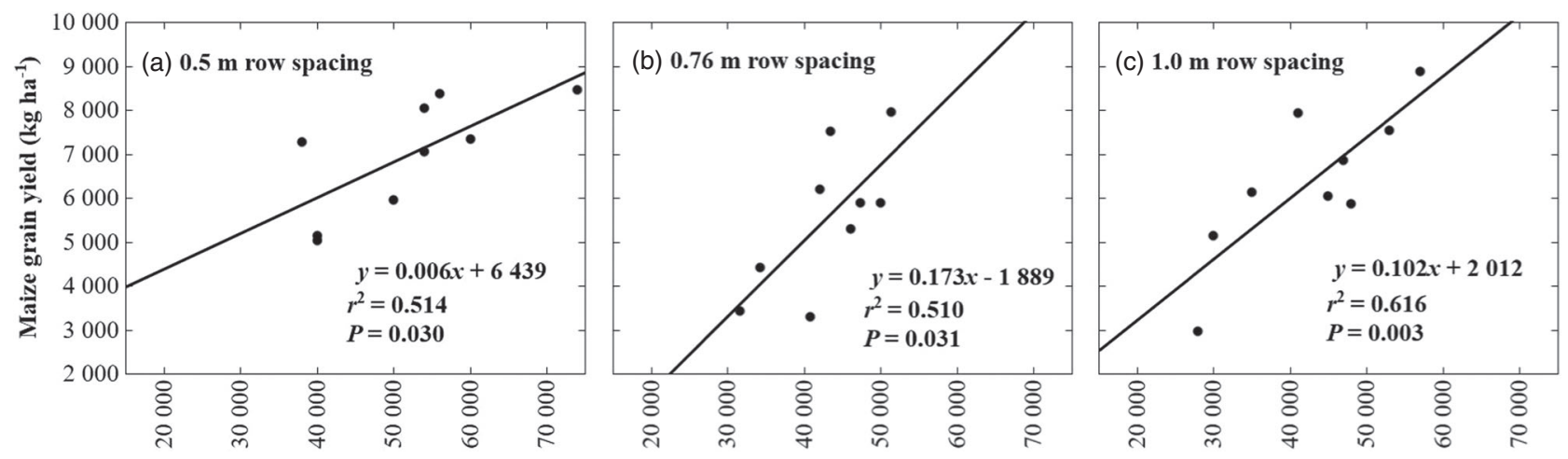

Final plant population $\left(\mathrm{ha}^{-1}\right)$

F I G U R E 3 The response of maize grain yield to plant population in Season 3 at (a) 0.5-, (b) 0.76-, and (c) 1.0-m row spacing

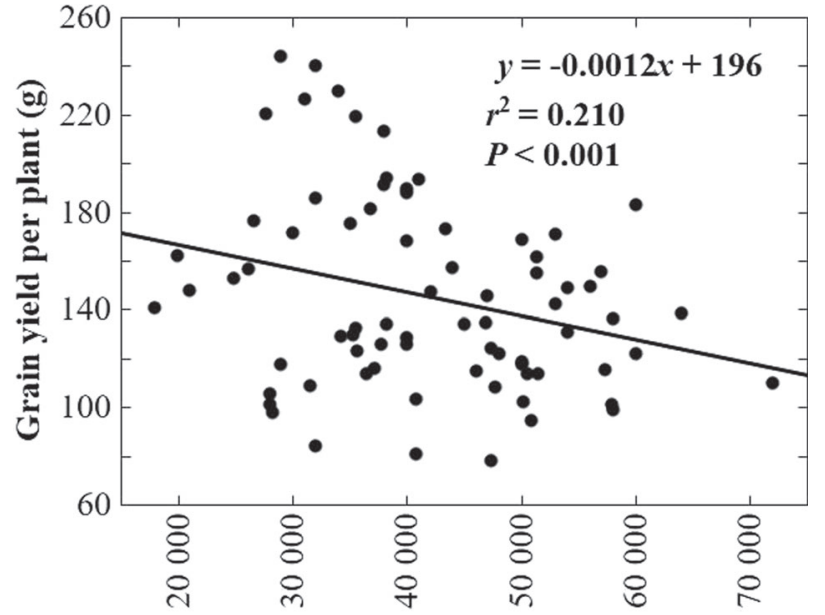

Final plant population $\left(\mathrm{ha}^{-1}\right)$

F I G U R E 4 The response of grain yield per plant to plant population across seasons and row spacings

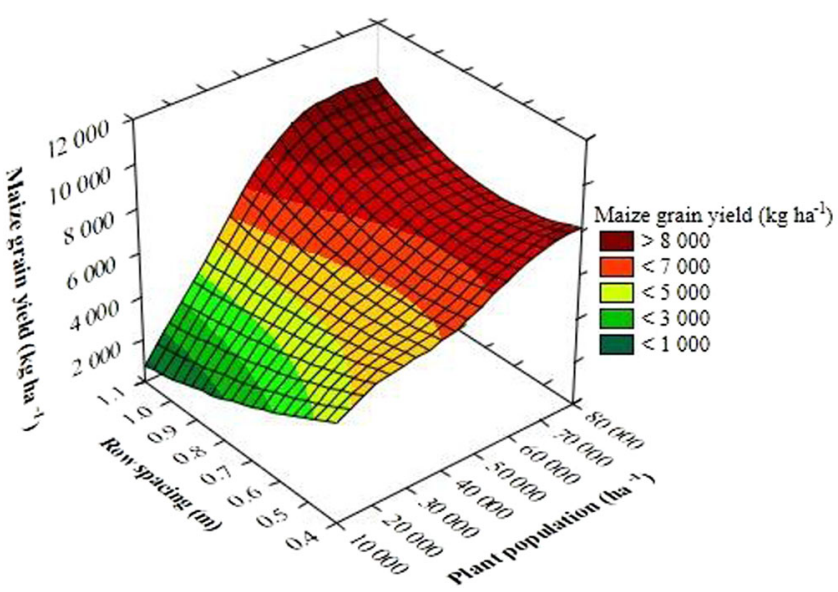

F I G U R E 5 The relationship between the responses of maize grain yield to the combined effect of plant population and row spacing highest maize grain yield was found when plant population ranged between 60,000 and 70,000 plants $\mathrm{ha}^{-1}$, reflecting a yield of $8,000-10,000 \mathrm{~kg} \mathrm{ha}^{-1}$. Overall, the lowest maize grain yield was found when plant population was lower than 20,000 plants $\mathrm{ha}^{-1}$ at a row spacing of $0.8 \mathrm{~m}$ or wider.

\subsection{Soil temperature}

From 60 DAE onwards, daily average soil temperature was higher with $1.0-\mathrm{m}$ row spacing than with $0.5-\mathrm{m}$ row spacing throughout the soil profile (Figures $6 \mathrm{~b}$ and $6 \mathrm{c}$ ) although the effect was only significant during the 60-90 DAE growth period. Pairwise comparisons between soil temperature at the two spacings at each soil depth measured were not significant. Plant population had no effect $(P>.05)$ on daily average soil temperature in Season 3, with only some evidence $(P<.1)$ suggesting the higher plant population resulted in lower daily average soil temperature during the 90-120 DAE growth period of Season 3. Since only depth influenced soil temperatures in Season 3, data are not shown.

\section{5 | Soil water availability}

In Season 2, increasing plant population reduced PPAW $(P<.05)$ throughout the $20-$ to $80-\mathrm{cm}$ soil layer, while there was no effect of row spacing nor a significant interaction between plant population and row spacing on PPAW (Figure 7). On average, the PPAW at 28,000 and 50,200 plants ha ${ }^{-1}$ across row spacings were 56 and $51 \%$ in the $20-$ to $40-\mathrm{cm}$ soil layer, corresponding to a soil water content of 11.87 and $10.81 \mathrm{~mm}$, respectively. The PPAW was on average 58 and $49 \%$ in the $40-$ to $60-\mathrm{cm}$ soil layer at 28,000 and 50,200 plants $\mathrm{ha}^{-1}$ during the 30-120 DAE growth period, respectively $(P<.05)$. The high rainfall at 75 DAE was 

(a) 30-60 DAE

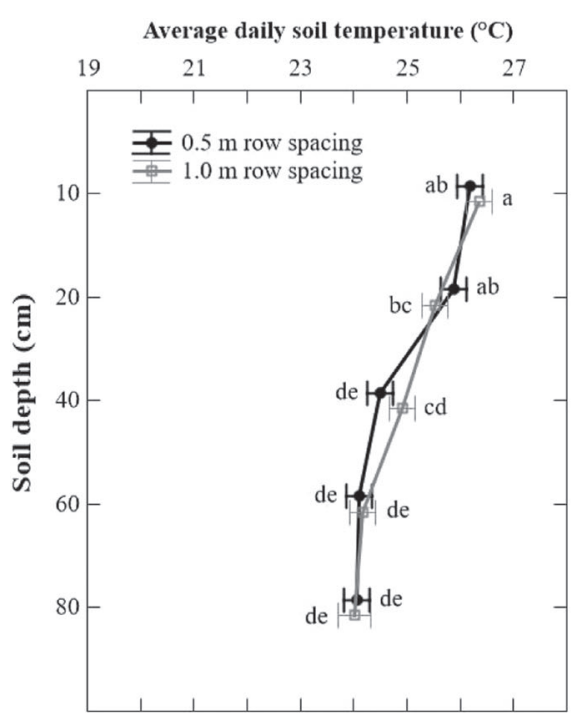

(b) $60-90 \mathrm{DAE}$

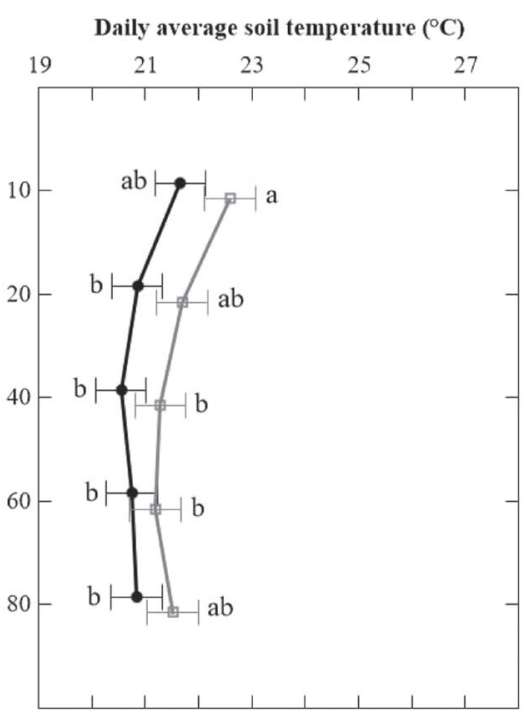

(c) $90-120 \mathrm{DAE}$

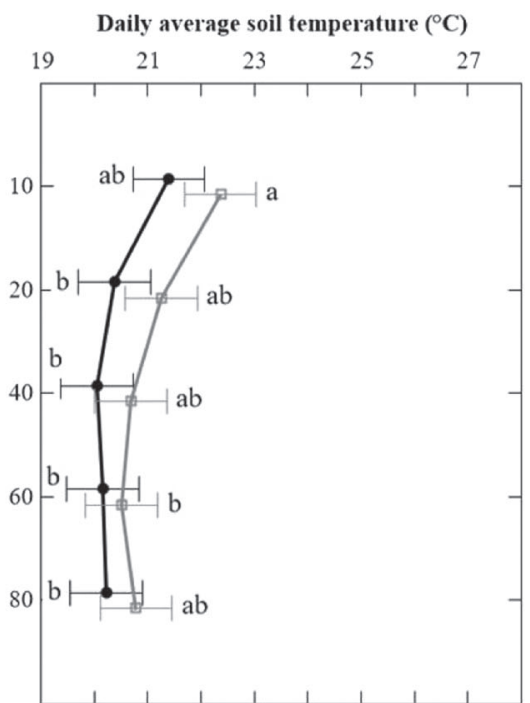

F I G U R E 6 A comparison of the daily average soil temperature in Season 2 (2016-2017) at 0.5- and 1.0-m row spacing with soil depth at (a) 30-60, (b) 60-90, and (c) 90-120 d after emergence (DAE). Means followed by a different letter indicate significant differences at $P<.05$
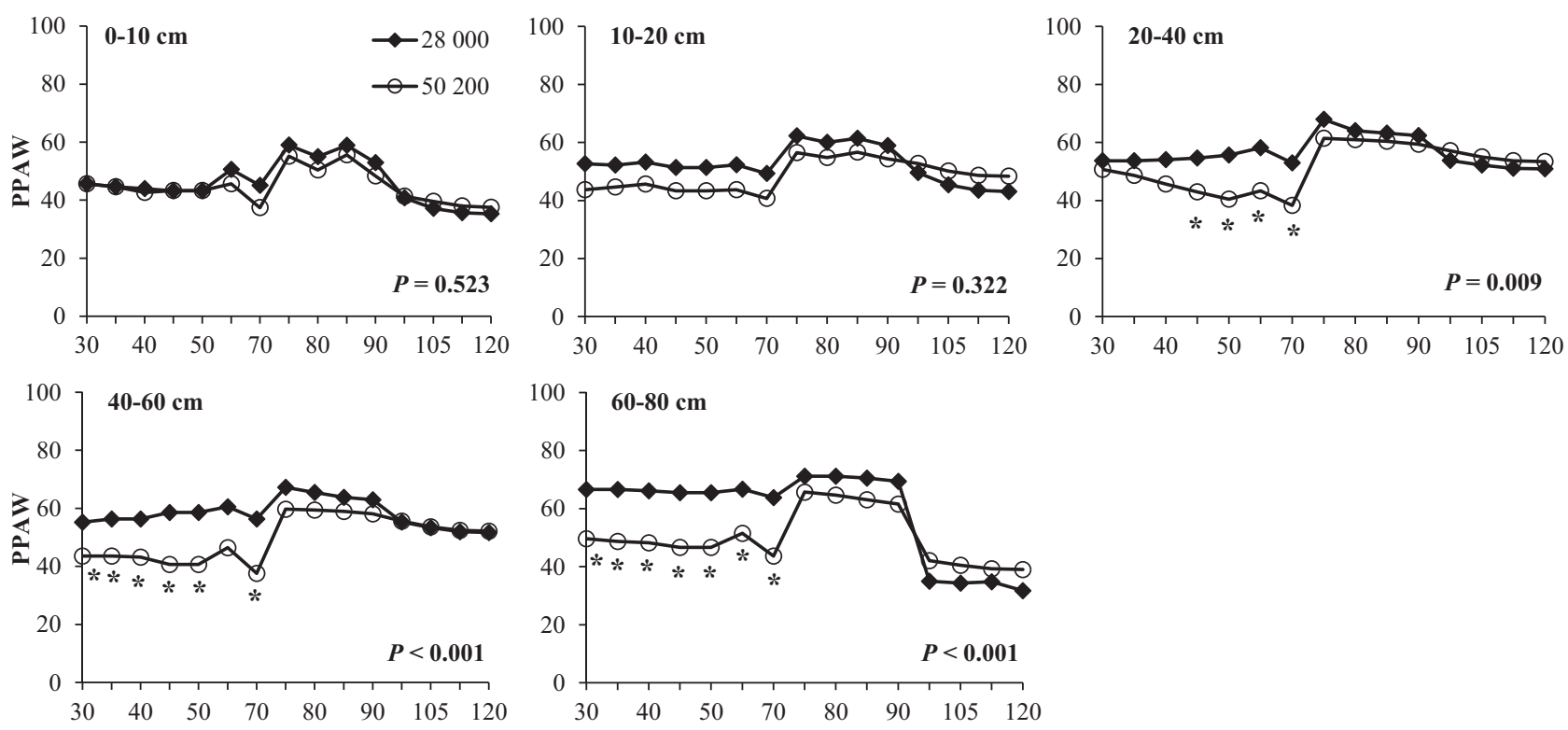

Days after emergence

F I G U R E 7 A comparison of percentage plant available water (PPAW) in Season 2 between plant population treatments at 10- to 20-cm soil depth increments to $80-\mathrm{cm}$ deep, from 30-120 d after emergence. Main effects of plant population is reported and significant differences between plant population treatments at $P<.05$ are indicated by an asterisk

apparent in the PPAW of the top 20-cm soil layer, resulting in an increase in average PPAW of approximately 20\%. The high PPAW in the 10- to $20-\mathrm{cm}$ soil layer might be explained by a possible compacted layer at approximately $20-\mathrm{cm}$ soil depth, leading to the development of a perched water table following a rainfall event. The PPAW was higher $(P<.05)$ at 28,000 plants ha ${ }^{-1}$ than at 50,200 plants ha ${ }^{-1}$ during the first
70 DAE at the 40- to 60- and 60- to 80-cm soil layers where after the differences diminished.

Plant population affected $(P<.05)$ PPAW at all soil layers except at $10-20$ and $60-80 \mathrm{~cm}$ throughout Season 3 (Figure 8). The average PPAW in the 0 - to $10-\mathrm{cm}$ soil layer at plant populations 35,000 and 70,000 plants $\mathrm{ha}^{-1}$ across row spacings were 57 and $47 \%$ during the season, respectively. 

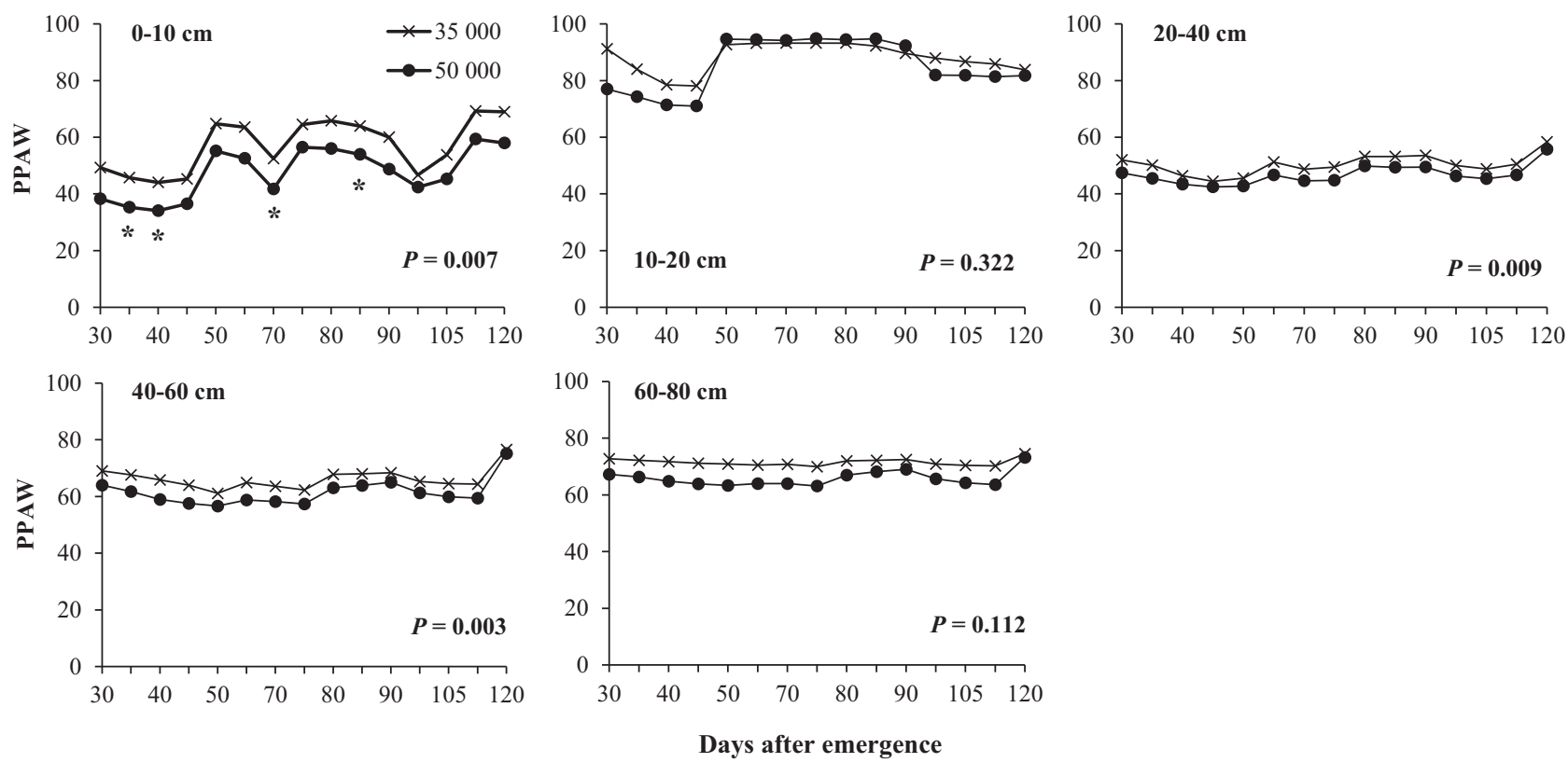

F I G U R E 8 A comparison of percentage plant available water (PPAW) in Season 3 between plant population treatments at 10- to 20-cm soil depth increments to 80-cm deep, from 30-120 d after emergence. Main effects of plant population is reported and significant differences between plant population treatments at $P<.05$ are indicated by an asterisk

The PPAW values correspond to 6.04 and $4.98 \mathrm{~mm}$ of accumulated soil water at 35,000 and 50,000 plants ha ${ }^{-1}$, respectively. The maize grain yield at 50,000 plants $^{h^{-1}}$ were higher $(P<.05)$ than the yield achieved at 35,000 plants $\mathrm{ha}^{-1}$, indicating the benefits of a high number of plants per unit area when favorable growing conditions prevail. The PPAW was inconsistent in the 0- to 10-cm soil layer in Season 3 , fluctuating between rainfall events for a plant population of 35,000 plants ha ${ }^{-1}$ between 50 and $70 \%$ and between 40 and $60 \%$ for 50,000 plants $\mathrm{ha}^{-1}$. The main effect of plant population at the 20- to $40-$ and $40-$ to $60-\mathrm{cm}$ soil layers was not sufficiently substantial to detect significant pairwise differences in PPAW between 35,000 and 50,000 plants ha ${ }^{-1}$. Overall, better rainfall distribution in Season 3 resulted in less variable PPAW at soil depths deeper than $10 \mathrm{~cm}$.

\section{4 | DISCUSSION}

The ability of modern maize hybrids to withstand stress factors more easily have enabled producers to achieve higher yields at increased plant populations worldwide (Duvick, 1997). However, the relationship between increased plant populations and higher yields is highly dependent, inter alia, on seasonal rainfall amounts and distribution throughout the growing season. The variability in maize grain yield achieved across seasons in this study support this statement, with average maize grain yield markedly greater in Season $2(7,530 \mathrm{~kg}$ $\mathrm{ha}^{-1}$ ) compared with 4,640 and $6,370 \mathrm{~kg} \mathrm{ha}^{-1}$ achieved during Seasons 1 and 3, respectively. The delayed planting date and dry conditions impeded overall growth and yield during Season 1. The higher soil water content during the critical growth periods in Season 2 due to adequate rainfall (Jan.Feb.; Table 1) provided optimal growing conditions for maize. Evaluation of the three-way relationship between maize grain yield, plant population, and row spacing revealed that yield was the greatest at high plant populations and wide row spacings (Figure 5) which is in contrast with previous findings (Sangoi, 2001).

The variability in maximum maize grain yield between seasons highlight the complexities involved when predicting optimum plant population and row spacing across different seasons and hybrids. Producers are understandably cautious to increase plant population considering the inconsistent rainfall pattern between seasons. Although a yield penalty is expected at low plant populations in years with good rainfall (Birch et al., 2008), less risk is involved, and producers resort to low plant populations $\left(<40,000\right.$ plants ha $\left.{ }^{-1}\right)$. In addition, Allen (2012) reported a negative maize grain yield response to increased plant population under no-tillage in seasons characterized with low rainfall. In contrast, the results obtained in our study indicated a positive maize grain yield response to plant population in the drier Season 1, suggesting higher plant populations are more favorable under CA.

In contrast to soil temperature, more significant differences in PPAW were observed between plant population treatments. The PPAW was higher $(P<.05)$ at 28,000 than at 50,200 plants $\mathrm{ha}^{-1}$ in Season 2. The higher plant population has led to earlier leaf canopy closure (Ottman \& Welch, 1989; Tetio-Kagho \& Gardner, 1988) thereby maximizing sunlight 
interception (Ottman \& Welch, 1989) and lowered evaporation losses from the soil surface (Karlen \& Camp, 1985). At the 28,000 plants ha $\mathrm{h}^{-1}$ and $1.0-\mathrm{m}$ row spacing configuration, PPAW was inefficiently used by plants and resulted in the lowest maize grain yield among all treatments. Poor leaf canopy cover and ineffective root system distribution across the interrow soil volume may have led to soil water losses through evaporation. Similar findings were reported by Barbieri et al. (2012) who found that a row spacing of $0.35 \mathrm{~m}$ consistently increased maize evapotranspiration compared to a wider $0.70-\mathrm{m}$ row spacing during early maize growth stages. It is clear that rapid canopy closure and a uniform and deep root system are critical aspects needed to efficiently utilize available soil water. This is especially important when producers opt to increase the number of plants per unit area in a rainfed maize production system where soil water is the most limiting factor for maize grain production. At high maize plant populations, root system architecture and related water-uptake is more critical than leaf canopy structure and sunlight interception for increasing biomass production and grain yield (Hammer et al., 2009). Research is needed to fully comprehend the dynamics between root system architecture and leaf canopy at varying maize plant population and row spacings configurations. This gap in knowledge should be met with field research under the various challenges set by soil and climate conditions.

Current plant population and row spacing recommendations in the eastern Free State range from 25,000 to 40,000 plants ha ${ }^{-1}$ at row spacings of $0.76 \mathrm{~m}$ and wider. These recommended guidelines were derived from plots under vigorous soil tillage and monoculture maize practices. Despite the low rainfall and late planting date during Season 1, maize grain yield indicated a positive response to increased plant population within each row spacing (Figure 1). This suggests increasing plant population may be an important consideration for farmers to realize modern hybrids' production potential and more efficient soil resource utilization under CA. With no clear response of maize grain yield to plant population and row spacing in Season 2, it is evident that the highest maize grain yields were not necessarily associated with the highest plant population. Overall, maize grain yield reached a plateau at approximately 65,000 plants ha $^{-1}$ with a maize grain yield of more than $8,000 \mathrm{~kg} \mathrm{ha}^{-1}$.

It is essential to consider the complete cropping system when choosing a suitable maize plant population and row spacing configuration. Additional factors to consider include inter alia livestock integration, resulting in two cropping system aspects competing for crop residues, that is, soil cover and animal feed. Rainfed maize is primarily produced on mixed crop-livestock farms in the eastern Free State. Crop residue utilization during winter months adds value to livestock, offers a more stable cashflow pattern throughout the year, and helps manage risk associated with grain production systems (Bell, Moore, \& Kirkegaard, 2014). Crop residues are a key feature of not only the success of no-tillage (Derpsch, Friedrich, Kassam, \& Li, 2010), but also the economic viability of the mixed rainfed crop-livestock systems, thus producers should apply agronomic management practices complementing increased crop residue production. An increase in biomass production has been associated with narrower row spacing (Cox, Cherney, \& Hanchar, 1998) and increased plant population without any maize grain yield penalty (Raymond, Alley, Parrish, \& Thomason, 2009). The higher harvest index (ratio of grain yield to biomass) of modern hybrids at higher plant populations is not as a result of increased biomass production but as a result of increased stress tolerance and their capacity to yield higher under stress conditions compared to older hybrids (Duvick, 2005). As a result, the yield potential of individual plants have not increased but rather the yield potential of a population of individual plants (Di Matteo et al., 2016).

The economic dynamics of higher plant populations (higher seed costs) under CA within a farming system is still unknown in the eastern Free State. It is suggested that future research focuses on an economic evaluation of varying plant population levels and associated yield returns, considering a wide variety of hybrids and fertilizer applications. It would be helpful to perform plant population and row spacing trials in diverse soil conditions and crop rotational sequences.

\section{5 | CONCLUSION}

Maize grain yield increased with increasing plant population at 0.5-, 0.76-, and 1.0-m row spacings in the drier Season 1 as well as in Season 3, which was characterized by more adequate and timely rainfall. Daily average soil temperature was reduced by narrower row spacing during the 60-90 DAE growth period in Season 2 with no significant difference between row spacing treatments during the rest of the growing season. Row spacing had no effect on PPAW in Season 2 and 3, however, average PPAW was higher at 28,000 compared to 50,200 plants $^{-1}$ during the 0-70 DAE growth period in the 40- to $80-\mathrm{cm}$ soil layer. Plant population affected PPAW in Season 3 at all soil layers except in the 10- to 20and $60-$ to $80-\mathrm{cm}$ soil layers. A higher PPAW was found at 35,000 plants ha ${ }^{-1}$ than at 70,000 plants ha ${ }^{-1}$. It appears that rapid maize leaf-canopy closure provided by increased plant population and narrower row spacing is critical to utilize the benefits associated with CA.

\section{ACKNOWLEDGEMENTS}

We thank Dr Hendrik Smith, Lientjie Visser, Jacques van Zyl, The Maize Trust, and the Riemland Study Group for supplying the data, their contributions and inputs. We thank Danie Slabbert for allowing the field experiments to be conducted on his farm. The Maize Trust, AgriSETA, and South African 
Society of Crop Production is acknowledged for providing funding to complete this work under respective $\mathrm{PhD}$ bursary programs. The South African Weather Service is thanked for providing valuable weather data on request.

\section{ORCID}

Stephanus J. Haarhoff (iD

https://orcid.org/0000-0001-7768-2845

Pieter A. Swanepoel

https://orcid.org/0000-0002-6481-0673

\section{REFERENCES}

Alessi, J., \& Power, J. F. (1974). Effects of plant population, row spacing, and relative maturity on dryland corn in the northern plains. I. Corn forage and grain yield. Agronomy Journal, 66, 316-319. https://doi.org/10.2134/agronj1974.00021962006600020037x

Allen, B. L. (2012). Dryland corn yield affected by row configuration and seeding rate in the northern Great Plains. Journal of Soil and Water Conservation, 67, 32-41. https://doi.org/10.2489/jswc.67.1.32

Balkcom, K. S., Satterwhite, J. L., Arriaga, F. J., Price, A. J., \& Van Santen, E. (2011). Conventional and glyphosate-resistant maize yields across plant populations in single- and twin-row configurations. Field Crops Research, 120, 330-337. https://doi.org/10.1016/ j.fcr.2010.10.013

Barbieri, P., Echarte, L., Della Maggiora, A., Sadras, V.O., Echeverria, H., \& Andrade, F. H. (2012). Maize evapotranspiration and wateruse efficiency in response to row spacing. Agronomy Journal, 104, 939-944. https://doi.org/10.2134/agronj2012.0014

Bell, L. W., Moore, A. D., \& Kirkegaard, J. A. (2014). Evolution in crop-livestock integration systems that improve farm productivity and environmental performance in Australia. European Journal of Agronomy, 57, 10-20. https://doi.org/10.1016/j.eja.2013.04.007

Berzsenyi, Z., Győrffy, B., \& Lap, D. (2000). Effect of crop rotation and fertilisation on maize and wheat yields and yield stability in a long-term experiment. European Journal of Agronomy, 13, 225-244. https://doi.org/10.1016/s1161-0301(00)00076-9

Birch, C. J., Stephen, K., McLean, G., Doherty, A., Hammer, G. L., \& Robertson, M. J. (2008). Reliability of production of quick to medium maturity maize in areas of variable rainfall in north-east Australia. Australian Journal of Experimental Agriculture, 48, 326-334. https://doi.org/10.1071/ea06104

Boomsma, C. R., Santini, J. B., Tollenaar, M., \& Vyn, T. J. (2009). Maize morphophysiological responses to intense crowding and low nitrogen availability: An analysis and review. Agronomy Journal, 101, 14261452. https://doi.org/10.2134/agronj2009.0082

Campos, H., Cooper, M., Habben, J. E., Edmeades, G. O., \& Schussler, J. R. (2004). Improving drought tolerance in maize: A view from industry. Field Crops Research, 90, 19-34. https://doi.org/ 10.1016/j.fcr.2004.07.003

Ciampitti, I. A., \& Vyn, T. J. (2012). Physiological perspectives of changes over time in maize yield dependency on nitrogen uptake and associated nitrogen efficiencies: A review. Field Crops Research, 133, 48-67. https://doi.org/10.1016/j.fcr.2012.03.008

Cox, J. W., Cherney, D. R., \& Hanchar, J. J. (1998). Row spacing, hybrid, and plant density effects on corn silage yield and quality. Journal of Production Agriculture, 11, 128-134. https://doi.org/ 10.2134/jpa1998.0128
De Boor, C. (1978). A practical guide to splines (pp. 325). New York: Springer.

De Boor, C. (1962). Bicubic spline interpolation. Journal of Mathematics and Physics, 41, 212-218. https://doi.org/10.1002/sapm19624 11212

Derpsch, R., Franzluebbers, A. J., Duiker, S. W., Reicosky, D. C., Koeller, K., Friedrich, T., ... Weiss, K. (2014). Why do we need to standardize no-tillage research? Soil and Tillage Research, 137, 1622. https://doi.org/10.1016/j.still.2013.10.002

Derpsch, R., Friedrich, T., Kassam, A., \& Li, H. (2010). Current status of adoption of no-till farming in the world and some of its main benefits. International Journal of Agricultural and Biological Engineering, 3, 1-25. https://doi.org/10.3965/j.issn.1934-6344.2010.01.0-0

Matteo, Di, A., J., Ferreyra, J. M., Cerrudo, A. A., Echarte, L., \& Andrade, F. H. (2016). Yield potential and yield stability of Argentine maize hybrids over 45 years of breeding. Field Crops Research, 197, 107-116. https://doi.org/10.1016/j.fcr.2016.07.023

Duvick, D. N. (1997). What is yield? In G. O. Edmeades, M. Bänziger, H. R. Mickelson, \& C. B. Peña-Valdivia (Eds.), Developing droughtand low N-tolerant maize: Proceedings of a symposium, El Batán, Mexico (pp. 332-335). Mexico City: CIMMYT.

Duvick, D. N. (2005). The contribution of breeding to yield advances in maize (Zea mays L.). In D. Sparks (Ed.), Advances in Agronomy (pp. 83-145). New York: Academic Press.

FAO, (2019). Food and Agriculture Organization. Conservation Agriculture. Retrieved from http://www.fao.org/conservation-agriculture/en/

Haarhoff, S. J., \& Swanepoel, P. A. (2018). Plant population and maize grain yield: A global systematic review of rainfed trials. Crop Science, 58, 1819-1829. https://doi.org/10.2135/cropsci2018.01.0003

Hajdu, I., Yule, I., Bretherton, M., Singh, R., \& Hedley, C. (2019). Field performance assessment and calibration of multi-depth AquaCheck capacitance-based soil moisture probes under permanent pasture for hill country soils. Agricultural Water Management, 217, 332-345. https://doi.org/10.1016/j.agwat.2019.03.002

Halvorson, A. D., Mosier, A. R., Reule, C. A., \& Bausch, W. C. (2006). Nitrogen and tillage effects on irrigated continuous corn yields. Agronomy Journal, 98, 63-71. https://doi.org/10.2134/agronj2005. 0174

Hammer, G. L., Dong, Z., McLean, G., Doherty, A., Messina, C., Schussler, J., ... Cooper, M. (2009). Can changes in canopy and/or root system architecture explain historical maize yield trends in the U.S. Corn Belt? Crop Science, 49, 299-312. https://doi.org/ 10.2135/cropsci2008.03.0152

Iragavarapu, T. K., \& Randall, G. W. (1995). Yield and nitrogen uptake of monocropped maize from a long-term tillage experiment on a poorly drained soil. Soil and Tillage Research, 34, 145-156. https://doi.org/10.1016/0167-1987(95)00470-d

Karlen, D. L., \& Camp, C. R. (1985). Row spacing, plant population and water management effects on maize in the Atlantic Coastal Plain. Agronomy Journal, 77, 393-398. https://doi.org/10.2134/ agronj1985.00021962007700030010x

Kottek, M., Grieser, J., Beck, C., Rudolf, B., \& Rubel, F. (2006). World map of the Köppen-Geiger climate classification updated. Meteorologische Zeitschrift, 15, 259-263. https://doi.org/10.1127/ 0941-2948/2006/0130

MacLaren, C., Storkey, J., Strauss, J. A., Swanepoel, P. A., \& Dehnen-Schmutz, K. (2018). Livestock in diverse cropping systems improve weed management and sustain yields whilst reducing inputs. Journal of Applied Ecology, 56, 144-156. https://doi.org/10.1111/ 1365-2664.13239 
Ottman, M. J., \& Welch, L. F. (1989). Planting patterns and radiation interception, plant nutrient concentration, and yield in maize. Agronomy Journal, 81, 167-174. https://doi.org/10.2134/ agronj1989.00021962008100020006x

Peiretti, R., \& Dumanski, J. (2014). The transformation of agriculture in Argentina through soil conservation. International Soil and Water Conservation Research, 2, 14-20. https://doi.org/10.1016/ s2095-6339(15)30010-1

Pittelkow, C. M., Linquist, B. A., Lundy, M. E., Liang, X., Van Groenigen, K. J., Lee, J., ... van Kessel, C. (2015). When does no-till yield more? A global meta-analysis. Field Crops Research, 183, 156-168. https://doi.org/10.1016/j.fcr.2015.07.020

Pretorius, J. P., \& Human, J. J. (1987). The influence of time of planting and planting density on the duration and rate of grain filling of maize (Zea mays L.). (In Afrikaans.) South African Journal of Plant and Soil, 4, 61-64.

Qian, C., Yu, Y., Gong, X., Jiang, Y., Zhao, Y., Yang, Z., ... Zhang, W. (2016). Response of grain yield to plant population and nitrogen rate in spring maize hybrids released from 1970 to 2010 in Northeast China. The Crop Journal, 4, 459-467. https://doi.org/ 10.1016/j.cj.2016.04.004

Raymond, F. D., Alley, M. M., Parrish, D. J., \& Thomason, W. E. (2009). Plant density and hybrid impacts on corn grain and forage yield and nutrient uptake. Journal of Plant Nutrition, 32, 395-409. https://doi.org/10.1080/01904160802660727

Sangoi, L. (2001). Understanding plant density effects on maize growth and development: An important issue to maximize grain yield. Ciência Rural, 31, 159-168. https://doi.org/10.1590/s010384782001000100027

Saxton, K. E., \& Rawls, W. J. (2006). Soil water characteristic estimates by texture and organic matter for hydrologic solutions. Soil Science Society of America Journal, 70, 1569-1578. https://doi.org/ 10.2136/sssaj2005.0117

Schmugge, T. J., Jackson, T. J., \& McKim, H.L. (1980). Survey of methods for soil moisture determination. Water Resources Research, 16, 961-979. https://doi.org/10.1029/WR016i006p00961

Soil Classification Working Group. (1991). Soil classification: A taxonomic system for South Africa: Memoirs on the agricultural natural resources of South Africa No. 15. Dep. of Agric. Development, Pretoria, South Africa.

Soil Survey Staff. (2003). Keys to soil taxonomy. Washington, DC: USDA.
Svobodová, Z., Habuštová, O. S., Holec, J., Holec, M., Boháč, J., Jursík, M., ... Sehnal, F. (2018). Split application of glyphosate in herbicidetolerant maize provides efficient weed control and favors beneficial epigeic arthropods. Agriculture, Ecosystems \& Environment, 251, 171-179. https://doi.org/10.1016/j.agee.2017.09.018

Tetio-Kagho, F., \& Gardner, F. P. (1988). Responses of maize to plant population density. I. Canopy development, light relationships, and vegetative growth. Agronomy Journal, 80, 930-935. https://doi.org/ 10.2134/agronj1988.00021962008000060018x

Thierfelder, C., \& Wall, P. C. (2009). Effects of conservation agriculture techniques on infiltration and soil water content in Zambia and Zimbabwe. Soil and Tillage Research, 105, 217-227. https://doi.org/10.1016/j.still.2009.07.007

TIBCO Software. (2018). Statistica (data analysis software system), version 13. Palo Alto, CA: TIBCO Software.

Van Roekel, R. J., \& Coulter, J. A. (2011). Agronomic responses of corn to planting date and plant population. Agronomy Journal, 103, 14141422. https://doi.org/10.2134/agronj2011.0071

Verhulst, N., Govaerts, B., Verachtert, E., Castellanos-Navarrete, A., Mezzalama, M., Wall, P., ... Sayre, K. D. (2010). Conservation agriculture, improving soil quality for sustainable production systems? In R. Lal \& B. A. Steward (Eds.), Advances in soil science: Food security and soil quality (pp. 197-208). Boca Raton: CRC Press.

Westgate, M. E., Forcella, F., Reicosky, D. C., \& Somsen, J. (1997). Rapid canopy closure for maize production in the northern US corn belt: Radiation-use efficiency and grain yield. Field Crops Research, 49, 249-258. https://doi.org/10.1016/s03784290(96)01055-6

Widdicombe, W., \& Thelen, K. (2002). Row Width and Plant population Effects on Corn Grain Production in the Northern Corn Belt. Agronomy Journal, 94, 1020-1023. https://doi.org/10.2134/ agronj2002.1020

How to cite this article: Haarhoff SJ, Swanepoel PA. Narrow rows and high maize plant population improve water use and grain yield under conservation agriculture. Agronomy Journal. 2020;112:921-931. https://doi.org/10.1002/agj2.20085 